\title{
Differential distribution and defence involvement of antimicrobial peptides in
}

\section{mussel}

\author{
Guillaume Mitta ${ }^{1, *}$, Franck Vandenbulcke ${ }^{1, *}$,Thierry Noël${ }^{2}$, Bernard Romestand ${ }^{2}$, Jean Claude Beauvillain ${ }^{3}$, \\ Michel Salzet ${ }^{1}$ and Philippe Roch ${ }^{2, \mp}$
}

1'Laboratoire d'Endocrinologie des Annélides, Groupe de Neuroimmunité des Hirudinées, UPRES A 8017 CNRS, Université des Sciences et Technologies de Lille, 59655 Villeneuve d'Ascq, France

2Défense et Résistance chez les Invertébrés Marins (DRIM), IFREMER-CNRS-Université de Montpellier 2, 34095 Montpellier, France

3Unité 422 INSERM, 1 place de Verdun, 59045 Lille, France

*These two authors contributed equally to this work

¥Author for correspondence (e-mail: proch@ifremer.fr)

Accepted 15 May; published on WWW 10 July 2000

\section{SUMMARY}

In previous papers, we characterised 3 types of 4-kDa, cysteine-rich, cationic antimicrobial peptides: MGDs (for Mytilus galloprovincialis defensins), mytilins and myticins, which are abundant in the mussel hemocytes. In the present work, we revealed a differential distribution of the cells expressing the different genes. In addition, using confocal and electron microscopy, we confirmed that defensins and mytilins were partially located in different sub-types of circulating hemocytes although the peptides can be located

\section{INTRODUCTION}

Antimicrobial peptides are one of the innate immunity actors which were conserved along evolution. Last decade, they were purified from plants (Broekaert et al., 1995), invertebrates (Iwanaga et al., 1998; Bulet et al., 1999) and vertebrates (Lehrer and Ganz, 1999) and are suspected to be part of immune processes probably in all metazoa. Their involvement in anti-infectious processes, however, can be different. Some antimicrobial peptides are produced by epithelial cells which line the respiratory, gastrointestinal and genito-urinary tracts, where they constitute one of the first barriers preventing pathogen invasion. Many antimicrobial peptides have been discovered in the epithelia of plants, insects and mammals (Schroder, 1999). Other antimicrobial peptides are especially abundant in circulating cells. In the horseshoe crab, Limulus polyphemus, the peptides are stored in granules of hemocytes and released in the plasma upon stimulation by microbial substances, such as lipopolysaccharides and $\beta$-glucans (Iwanaga et al., 1998). In mammals, these molecules accumulate in granulocytes and certain macrophages to exert their microbicidal activity on engulfed bacteria (Ganz and Lehrer, 1997). Insects respond to septic injury by rapidly synthesising antimicrobial peptides. Predominantly produced in the fat body, insect antimicrobial peptides are secreted into hemolymph and participate in a systemic response (Hoffmann et al., 1996). in the same cell, and even in the same granule. We also demonstrated that mytilins exert their microbicidal effect within the cells through the process of phagosome-mytilin granule fusion leading to the co-location of ingested bacteria and mytilins.

Key words: Antimicrobial, Defensin, Mytilin, Myticin, Mussel, Hemocyte, Innate immunity

In arthropods, antimicrobial peptides are one of the hallmarks of the antimicrobial host defence. Until recently, these peptides were unknown in other invertebrate phyla. Applying the same methodology used for isolating antimicrobial peptides from insects, numerous antimicrobial peptides have been characterised from mussel hemolymph. These small, cationic, cysteine-rich antimicrobial peptides are organised into 4 groups according to the features of their primary structure and consensus cysteine array (Table 1). The first group comprises molecules belonging to the arthropod defensin family. Two defensins, $\mathrm{A}$ and $\mathrm{B}$, containing 6 cysteines, have been characterised from Mytilus edulis plasma (Charlet et al., 1996) and a defensin-like peptide, MGD1 (for Mytilus galloprovincialis defensin-1), containing 8 cysteines from plasma and hemocytes of such mussel (Hubert et al., 1996; Mitta et al., 1999b). A second isoform, MGD2, was identified from hemocyte mRNA (Mitta et al., 1999b). The second group of molecules, mytilins, comprises 5 isoforms (A, B, C, D and G1). A and B isoforms were isolated from $M$. edulis plasma (Charlet et al., 1996), and B, C, D and G1 isoforms from M. galloprovincialis hemocytes (Mitta et al., 2000). The third group of peptides, myticins, were characterised from plasma (A isoform) and hemocytes (A and B isoforms) of M. galloprovincialis (Mitta et al., 1999a). In addition, an antifungal peptide of $6.5 \mathrm{kDa}$ containing 12 cysteines has been partially characterised from $M$. edulis plasma (Charlet et al., 1996). 


\section{Table 1. Diversity of the mussel antimicrobial peptide families: defensins (A), mytilins (B), myticins (C) and mytimycin (D)}
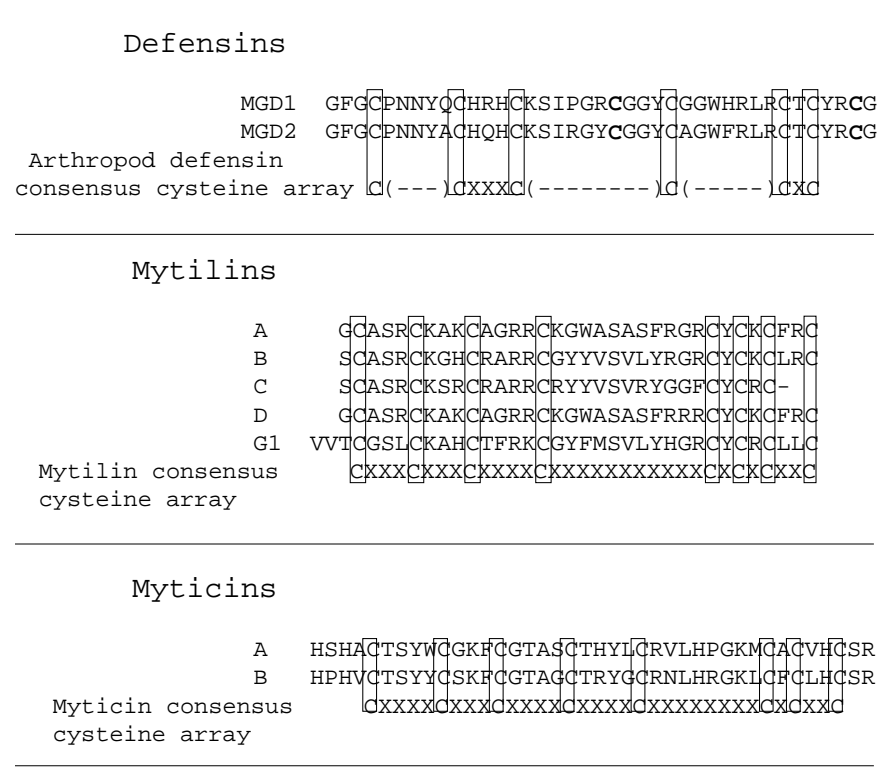

Mytimycin

DCCRKPFRKHCWDCTAGTPYYGYSTRNIFGCTC---

Cysteines are boxed evidencing the consensus cysteine arrays. The two extra cysteines of the mussel defensins (MGD1 and MGD2) are in bold.

Recent works have shown that defensins, mytilin $\mathrm{B}$, and myticins $\mathrm{A}$ and $\mathrm{B}$, are produced as precursor molecules processed to active compounds within the hemocytes ((Mitta et al., 1999a,b, 2000). Furthermore, previous studies have shown that defensins and mytilins are stored in granulocytes. Immunocytochemistry at the ultrastructural level showed that defensins (i) are predominantly located in vesicles of a granulocyte subclass containing small granules, but (ii) are also found in large granules of the other granulocyte subclass containing large granules (Mitta et al., 1999b). Mytilin labelling was exclusively present in hemocytes exhibiting large granules and particularly concentrated in their large granular structures (Mitta et al., 2000). Consequently, defensins and mytilins seem to be partially distributed in the same hemocyte subclass. In addition, the participation of mytilins in antiinfectious processes was investigated by submitting mussels to bacterial challenge. In such experiments, migration and adherence of mytilin containing hemocytes around the injection site were evidenced (Mitta et al., 2000). This indicated a local participation of mytilins in the antimicrobial response. Mytilins could be (i) massively secreted into the immediate hemocyte environment or (ii) exert their microbicidal activity on engulfed bacteria within the cells.

In the present study, we report the distribution of defensin MGD1, mytilin B and myticin B expressing cells throughout the mussel tissues using in situ hybridisation. Then, using confocal and electron microscope observations, we compare the distribution of defensins and mytilins in the population of circulating hemocytes. Finally, in order to determine how mytilins, transported by circulating hemocytes around the injection site, act on bacteria, hemocytes were confronted with bacteria in vitro.

\section{MATERIALS AND METHODS}

\section{Animals}

Adult mussels (Mytilus galloprovincialis) were collected from a shellfish farm (Palavas, France, Gulf of Lion).

\section{Bacteria and bacteria labelling}

Vibrio alginolyticus (DSMZ 2171), pathogenic for larvae and not for adult mussel (Anguiano-Beltran, 1996), were grown at $25^{\circ} \mathrm{C}$ for 24 hours in Mueller Hinton Broth medium (Difco) supplemented with $\mathrm{NaCl}(15 \mathrm{~g} / \mathrm{l})$, then centrifuged $(9,000 \mathrm{~g}$ for 20 minutes) and suspended in filtered sea water $(0.45 \mu \mathrm{m})$ before heat killing for 2 hours at $65^{\circ} \mathrm{C}$.

Heat-killed $V$. alginolyticus were washed in phosphate buffer saline (PBS), then labelled by incubation for 1 hour at $25^{\circ} \mathrm{C}$ in $0.1 \mathrm{M}$ $\mathrm{NaHCO}_{3}, \mathrm{pH} 9.6,0.01 \mathrm{mg} / \mathrm{ml}$ FITC (Sigma). Bacteria were pelleted at $12,500 \mathrm{~g}$ for 5 minutes, washed free of unbound fluorochrome with PBS and kept at $-20^{\circ} \mathrm{C}$ until used.

\section{Phagocytosis assays}

After collection with a syringe from the posterior adductor muscle, hemolymph was kept on ice in $14 \mathrm{ml}$ Falcon tubes. For electron microscopy, heat-killed bacteria were immediately added, according to the ratio 50 bacteria per hemocyte, and incubated for 20 minutes at room temperature. $10^{7}$ cells were then centrifuged for 15 minutes at $800 \mathrm{~g}$ and $4{ }^{\circ} \mathrm{C}$, and the pellet treated for single immunogold staining. For confocal microscopy, labelled bacteria were added to hemolymph ( 50 bacteria per hemocyte) and incubation was performed at room temperature. After various incubation periods $(1,10,20$ minutes), cells were fixed and treated for immunofluorescence microscopy (see below).

\section{cDNA probes}

Defensin MGD1 (GenBank accession number AF162337), mytilin B (accession number AF162336) and myticin B (accession number AF162335) cDNAs were obtained from previous studies after screening of a cDNA library prepared from M. galloprovincialis hemocytes (Mitta et al., 1999a,b, 2000).

\section{In situ hybridisation}

Probes

Digoxigenin(DIG)-11-UTP-labelled antisense and sense riboprobes were generated by in vitro transcription using Dig RNA labelling kit and T3 RNA polymerase (Boehringer Mannheim).

\section{Tissue preparation}

Tissues from adult mussels were fixed in a solution containing $13 \%$ formalin, $39 \%$ ethanol and $0.65 \%$ ammonium hydroxide, $\mathrm{pH}$ 6.4. After dehydration, tissues were embedded in Paraplast and $8 \mu \mathrm{m}$ sections were cut, mounted on poly-L-lysin coated slides and stored at $4^{\circ} \mathrm{C}$ until use.

\section{Hybridisation}

The hybridisation protocol was adapted from that of Faure-Virelizier et al. (1998). DIG-labelled riboprobes (approximately 20-50 ng RNA per section) were diluted in hybridisation buffer containing $50 \%$ formamide, $10 \%$ dextran sulfate, $10 \times$ Denhardt's solution, $0.5 \mathrm{mg} / \mathrm{ml}$ tRNA from E. coli, $100 \mathrm{mM}$ dithiothreitol (DTT) and $0.5 \mathrm{mg} / \mathrm{ml}$ salmon sperm DNA. Hybridisation was carried out overnight at $55^{\circ} \mathrm{C}$. The sections were then washed twice $(2 \times 30$ minutes) with $2 \times$ SSC (standard saline citrate), treated with RNase A $(20 \mu \mathrm{g} / \mathrm{ml}$ in $2 \times$ SSC) 
for 30 minutes at $37^{\circ} \mathrm{C}$ and consecutively rinsed $2 \times 30$ minutes at $55^{\circ} \mathrm{C}$.

After 2 washes with DIG buffer $(0.1 \mathrm{M}$ Tris, $\mathrm{pH} 7.5,0.1 \mathrm{M} \mathrm{NaCl})$, sections were incubated for 16 hours at $20^{\circ} \mathrm{C}$ with alkaline phosphatase-conjugated sheep anti-DIG antibody (Boehringer) diluted 1:1,000 in DIG buffer containing 1\% normal sheep serum and $0.05 \%$ Triton X-100. After washes, bound antibodies were visualised by incubation $\left(6\right.$ hours, darkness, $20^{\circ} \mathrm{C}$ ) in $0.1 \mathrm{M}$ Tris, $\mathrm{pH} 9.5,50 \mathrm{mM}$ $\mathrm{MgCl}_{2}, 0.1 \mathrm{M} \mathrm{NaCl}, 375 \mu \mathrm{g} / \mathrm{ml}$ nitroblue tetrazolium, $188 \mu \mathrm{g} / \mathrm{ml} 5$ bromo-4-chloro-3-indolyl phosphate, $1 \mathrm{mM}$ levamisole and $1.3 \%$ dimethyl sulfoxide. The chromagen reaction was stopped by rinsing the slides in DIG buffer and the dehydrated slides coverslipped with XAM (Merck) mounting medium.

Control for in situ hybridisation consisted of replacing antisense riboprobe with sense riboprobe. RNase control sections were obtained by adding $10 \mu \mathrm{g} / \mathrm{ml}$ RNase $\mathrm{A}$ in the buffer during the proteinase $\mathrm{K}$ treatment.

\section{Defensin MGD1 peptide synthesis}

MGD1 peptide was synthesised using solid-phase Fmoc protection groups on a 9050 Pepsynthesiser apparatus (Milligen). Protected groups were removed by $\mathrm{K}$ reagent and crude peptide was purified by reverse-phase HPLC on a $\mathrm{C}_{18}$ preparative column.

\section{Anti-defensins and anti-mytilins antibodies}

Mouse polyclonal anti-defensin antiserum was prepared by glutaraldehyde coupling of synthetic defensin MGD1 to ovalbumin. Four Balb/c mice were immunised by 3 subcutaneous injections of $150 \mu \mathrm{l}$ PBS containing $8 \mu \mathrm{g}$ MGD1, $10 \mu \mathrm{g}$ ovalbumin in $150 \mu \mathrm{l}$ complete Freund's adjuvant. Ascites were collected 2 weeks after intraperitoneal injection with $5 \times 10^{6}$ mice tumour cells in $500 \mu \mathrm{RPMI}$ 1640 (Gibco) and tested by ELISA against native defensin MGD1.

Anti-mytilin B antibody (IgGs) was a rabbit antibody described in a previous study (Mitta et al., 2000).

\section{Confocal microscopy}

\section{Double immunofluoresence}

Hemolymph was collected under 1 volume of anti-aggregant modified Alsever solution (MAS) buffer (Bachère et al., 1991). Then, cells were fixed for 30 minutes in 1 volume of ice-cold $8 \%$ paraformaldehyde in
0.1 M PBS containing $10 \%$ saccharose. Cells were centrifuged on slides for 5 minutes at $1,000 \mathrm{rpm}$ in a cytospin. After 1 hour incubation in TBS $(0.1 \mathrm{M}$ Tris, $\mathrm{pH} 7.5,0.9 \% \mathrm{NaCl})$ containing $3 \%$ normal goat serum (NGS), the cells were incubated overnight at $20^{\circ} \mathrm{C}$ in TBS containing 1:500 mouse anti-defensin antiserum, $10 \mu \mathrm{g} / \mathrm{ml}$ rabbit antimytilin IgG, $2 \%$ NGS, $0.01 \%$ Triton X-100. After washes, cells were incubated for 2 hours jointly with goat anti-mouse FITC- and goat anti-rabbit Texas-Red tagged antisera (Jackson Immunoresearch) diluted 1:100 in TBS, 2\% NGS. After washes, slides were mounted in glycerol containing $25 \%$ TBS and $0.1 \%$ p-phenylenediamine. The absence of secondary antibodies cross-reactivity was controlled by omitting one or both of the primary antibodies.

\section{Phagocytosis and immunofluorescence}

After incubation with FITC-labelled bacteria, hemocytes were fixed for 30 minutes in 1 volume of ice-cold $8 \%$ paraformaldehyde in 0.1 M PBS, $10 \%$ saccharose. Cells were centrifuged on slides for 5 minutes at $1,000 \mathrm{rpm}$ in a cytospin. After 1 hour incubation in TBS containing $3 \% \mathrm{NGS}$, the cells were incubated overnight at $20^{\circ} \mathrm{C}$ with $10 \mu \mathrm{g} / \mathrm{ml}$ rabbit anti-mytilin IgGs in TBS, $2 \%$ NGS, $0.01 \%$ Triton X100. After washes, cells were incubated for 2 hours with 1:100 goat anti-rabbit Texas-Red tagged antiserum (Jackson Immunoresearch) in TBS containing $2 \%$ NGS. The slides were then mounted with glycerol containing $25 \%$ TBS, $0.1 \%$ p-phenylenediamine, and examined with a confocal microscope.

Labelled cells were observed using a Leica laser scanning microscope (TCS NT) equipped with a Leica (DMIRBE) inverted microscope and an argon/krypton laser. FITC signal was detected using a $488 \mathrm{~nm}$ band-pass excitation filter and a 575-640 nm pass barrier filter, and Texas-Red signal by exciting samples at $568 \mathrm{~nm}$. Images were acquired sequentially as single transcellular optical sections and averaged over 16 scans/frame.

\section{Light microscopy}

To study mytilin immune reactivity on enterocytes, tissues from adult mussels were fixed as describe above. After dehydration, tissues were embedded in Paraplast and $8 \mu \mathrm{m}$ sections were cut, mounted on glass slides and stored at $4^{\circ} \mathrm{C}$ in a dry atmosphere until use. After hydration, the sections were treated as follow: (1) 10 minutes at $20^{\circ} \mathrm{C}$ in PBS, $\mathrm{pH} 7.4$; (2) 1.5 hour at $20^{\circ} \mathrm{C}$ in PBS containing 5\% BSA, $0.1 \%$ gelatin

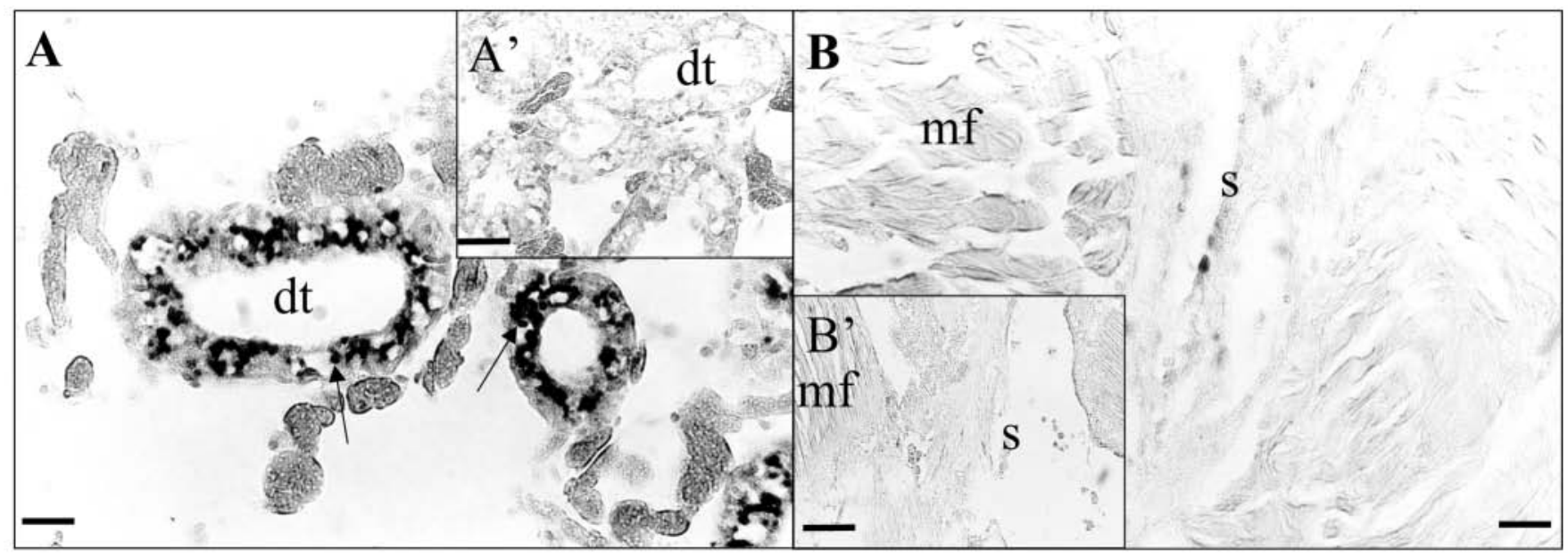

Fig. 1. Detection of defensin MGD1 mRNA in mussel tissues by in situ hybridisation. (A and B) Paraffin-embedded sections of mussels were hybridised with defensin MGD1 antisense riboprobes labelled with DIG-UTP and revealed using alkaline phosphatase-conjugated antibodies. Labelling appears in the epithelia of digestive tubules (A). The shape of these cells (arrows) evokes infiltrating hemocytes. One positive hemocyte is also present in sinus (B). ( $\mathrm{A}^{\prime}$ and $\left.\mathrm{B}^{\prime}\right)$ Negative controls consisting in low magnification of digestive tubules $\left(\mathrm{A}^{\prime}\right)$ and adductor muscle sinus (B') hybridised with defensin MGD1 sense riboprobes. dt, digestive tubule; mf, muscular fibers; s, sinus. Bars: $60 \mu \mathrm{m}$ (A and B); $140 \mu \mathrm{m}\left(\mathrm{A}^{\prime}\right.$ and $\left.\mathrm{B}^{\prime}\right)$. 


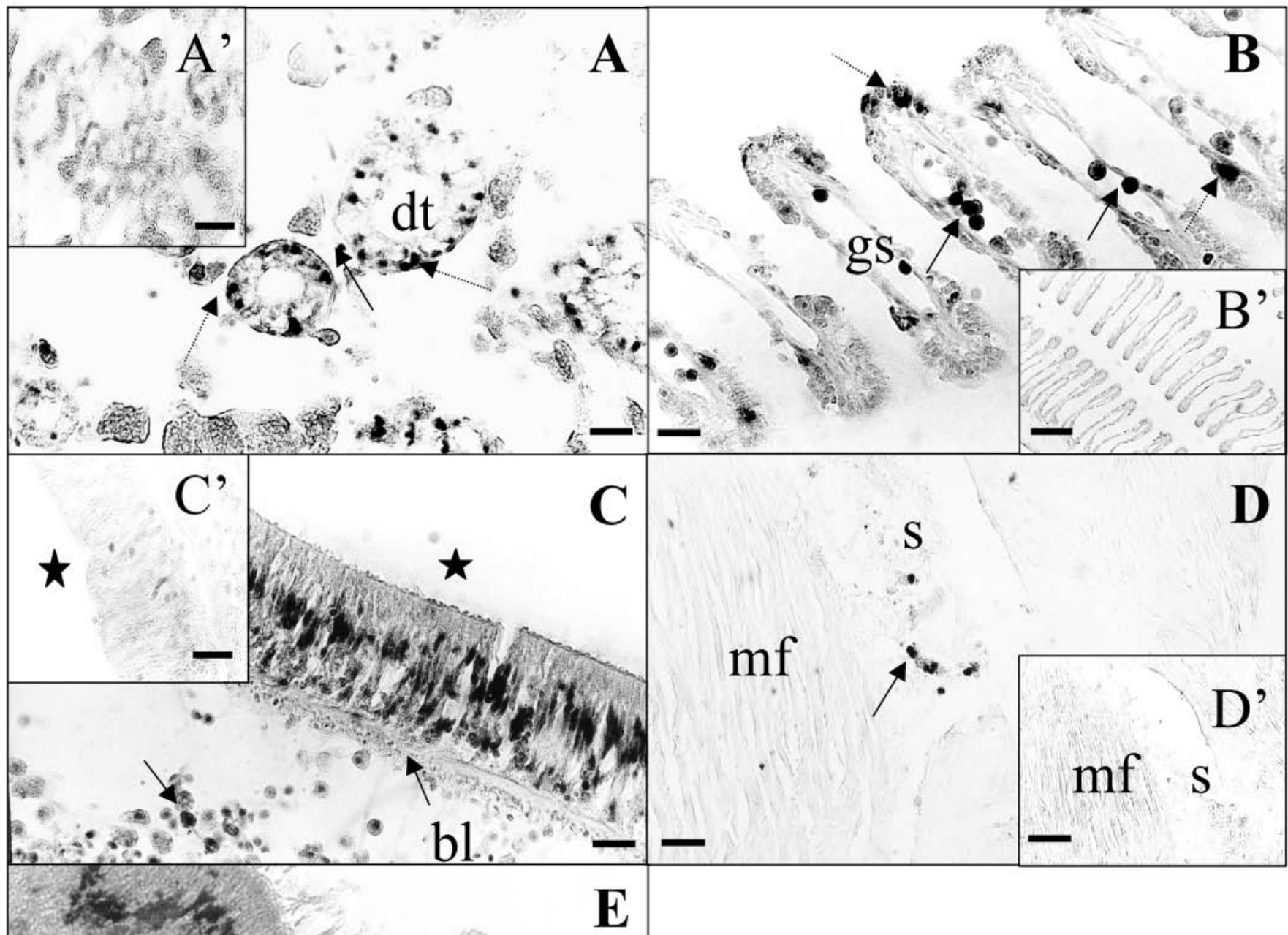

Fig. 2. Detection of mytilin B mRNA and peptide in mussel tissues. Paraffin-embedded sections of mussels were hybridised with antisense $(A, B, C, D)$ or sense $\left(A^{\prime}, B^{\prime}, C^{\prime}, D^{\prime}\right)$ mytilin $B$ riboprobes labelled with DIG-UTP and revealed using alkaline phosphatase-conjugated antibodies. Positive cells are particularly abundant in digestive gland (A), gills (B), intestine (C) and adductor muscle sinus (D). In C, the shape of positive cells suggests that they are enterocytes. In other tissues, positive cells are probably free hemocytes in sinuses (arrows) or infiltrating in epithelia (B dotted arrows). (E) Immune detection of mytilin B in paraffin sections of intestine. bl, basal lamina, dt, digestive tubule; gs, gill sinus; mf, muscular fibers; $\mathrm{s}$, sinus; star, lumen of the intestine. Bars: $60 \mu \mathrm{m}$ (A and D); 30 $\mu \mathrm{m}(\mathrm{B}$ and $\mathrm{C}) ; 140 \mu \mathrm{m}\left(\mathrm{A}^{\prime}\right.$ and $\left.\mathrm{D}^{\prime}\right) ; 150 \mu \mathrm{m}\left(\mathrm{B}^{\prime}\right) ; 75 \mu \mathrm{m}\left(\mathrm{C}^{\prime}\right)$.

and $1 \%$ NGS; (3) 1 hour at $20^{\circ} \mathrm{C}$ with anti-mytilin IgGs $(10 \mu \mathrm{g} / \mathrm{ml})$ in buffer I (PBS containing 1\% BSA, $0.1 \%$ gelatin, $1 \%$ NGS); (4) $3 \times$ 10 minutes in PBS, (5) 2 hours at $20^{\circ} \mathrm{C}$ with $1 \mathrm{~nm}$ colloidal goldlabelled goat anti-rabbit IgG (Amersham) diluted 1:50 in buffer I; (6) $3 \times 10$ minutes in PBS; (7) $2 \times 5$ minutes equilibration in $0.2 \mathrm{M}$ citrate buffer, pH $7.4(\mathrm{CB})$; (8) 15 minutes at $20^{\circ} \mathrm{C}$ of silver amplification with the IntenSE ${ }^{\mathrm{TM}} \mathrm{M}$ kit according to the manufacturer's instructions (Amersham); (8) $2 \times 2$ minutes in distilled water. The sections were then stained with Evans blue and examined with a light microscope.

\section{Electron microscopy}

Double immunogold labelling

After hemolymph collection under 1 volume of MAS buffer, cell pellets $\left(10^{7}\right.$ cells per pellet $)$ were obtained by 10 minutes centrifugation at $800 \mathrm{~g}$. Cell were fixed for 2 hours at $4^{\circ} \mathrm{C}$ in PBS containing $4 \%$ paraformaldehyde, $0.2 \%$ picric acid, $0.1 \%$ glutaraldehyde. Cells were post-fixed in $1 \% \mathrm{OsO}_{4}$ for 5 minutes and dehydrated before embedding in LR white (TAAB). Immune staining was performed on $90 \mathrm{~nm}$ thick ultrathin sections cut from the embedded pellets and collected on nickel grids. Sections were treated as follows: (1) 8 minutes in $10 \% \mathrm{H}_{2} \mathrm{O}_{2}$; (2) 10 minutes in distilled water; (3) 10 minutes in TBS containing $1 \%$ NGS and $1 \%$ BSA (TBSNGS-BSA); (4) 48 -hours at $4^{\circ} \mathrm{C}$ in TBS-NGS-BSA containing 1:500 diluted mouse anti-defensin antiserum and $10 \mu \mathrm{g} / \mathrm{ml}$ rabbit antimytilin IgGs; (5) 3× 10 minutes in TBS-NGS-BSA; (6) 1.5 -hours in TBS-NGS-BSA containing 15 (or 5) nm colloidal gold-labelled goat anti-rabbit IgG (Amersham) and 5 (or 18) nm colloidal gold-labelled goat anti-mouse IgG (Amersham and Jackson, respectively) diluted 


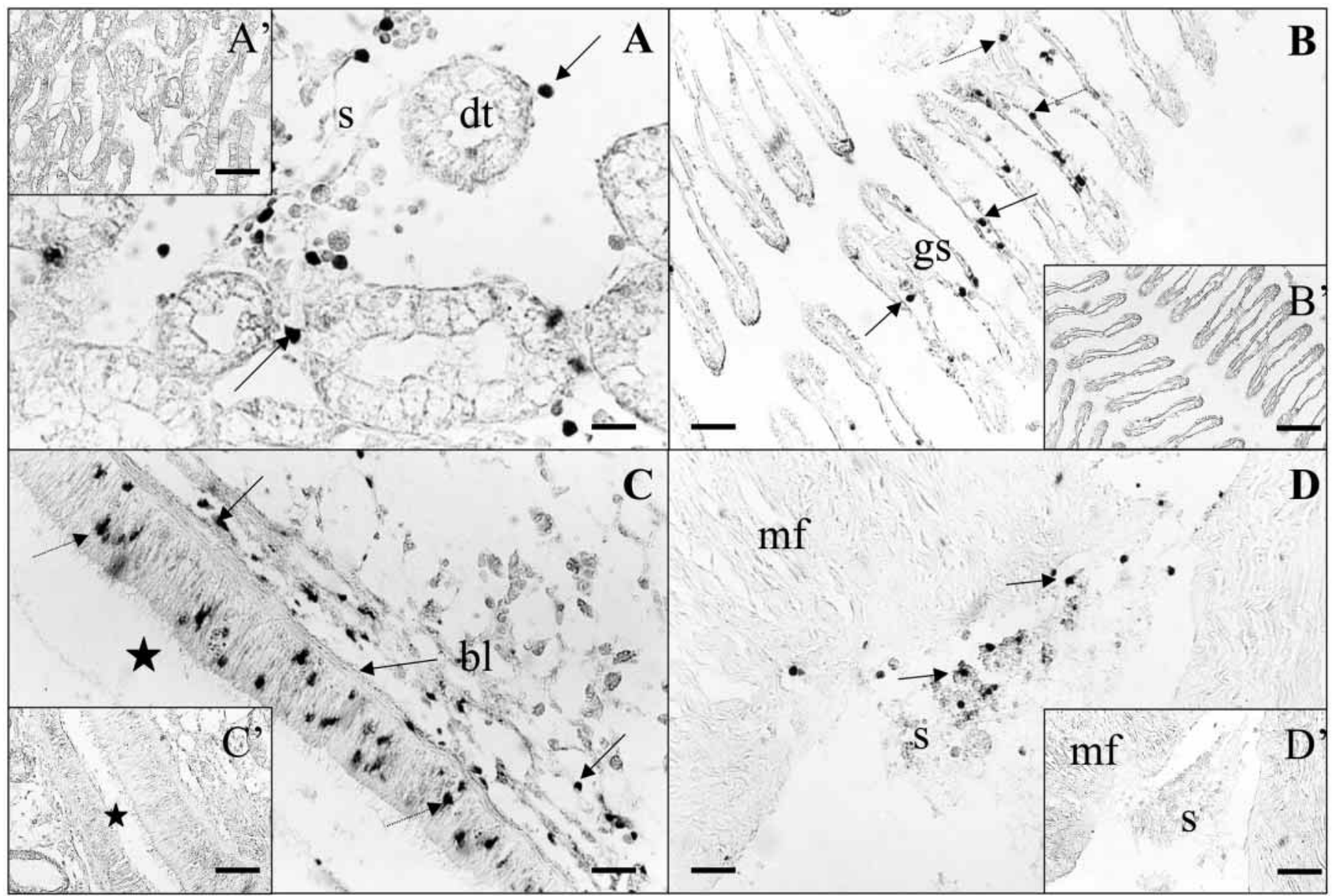

Fig. 3. Detection of myticin $B$ mRNA in mussel tissues by in situ hybridisation. Paraffin-embedded sections of mussels were hybridised with antisense $(\mathrm{A}, \mathrm{B}, \mathrm{C}, \mathrm{D})$ or sense $\left(\mathrm{A}^{\prime}, \mathrm{B}^{\prime}, \mathrm{C}^{\prime}, \mathrm{D}^{\prime}\right)$ myticin $\mathrm{B}$ riboprobes labelled with DIG-UTP and revealed using alkaline phosphatase-conjugated antibodies. Positive cells are particularly abundant in digestive gland (A), gills (B), intestine (C) and adductor muscle sinus (D). They are probably free hemocytes in sinuses (arrows) or infiltrating in epithelia (dotted arrows). bl, basal lamina, dt, digestive tubule; gs, gill sinus; mf, muscle fibers; s, sinus; star, lumen of the intestine. Bars: $40 \mu \mathrm{m}(\mathrm{A}) ; 100 \mu \mathrm{m}(\mathrm{B}) ; 80 \mu \mathrm{m}\left(\mathrm{C}\right.$ and D); $200 \mu \mathrm{m}\left(\mathrm{A}^{\prime}\right) ; 200 \mu \mathrm{m}\left(\mathrm{B}^{\prime}\right) ; 220 \mu \mathrm{m}$ $\left(\mathrm{C}^{\prime}\right) ; 160 \mu \mathrm{m}\left(\mathrm{D}^{\prime}\right)$.

1:50; (7) $3 \times 10$ minutes in TBS; (8) 3 minutes in TBS, $1 \%$ glutaraldehyde; (9) $2 \times 5$ minutes in distilled water. Sections were then stained 12 minutes with uranyl acetate and examined with a Jeol JEM $100 \mathrm{CX}$.

\section{Single immunogold labelling}

After phagocytosis assay, cell pellets were obtained and treated as above except for step (4) and (6) which consisted in, step (4) 48 hours at $4^{\circ} \mathrm{C}$ in TBS-NGS-BSA containing $10 \mu \mathrm{g} / \mathrm{ml}$ rabbit anti-mytilin IgGs, and step (6) 1.5 hours in $15 \mathrm{~nm}$ colloidal gold-labelled goat antirabbit IgG (Amersham) diluted 1:50 in the precedent buffer.

\section{ELISA}

All washing procedures were performed 3 times in PBS, $\mathrm{pH} 7.4,0.1 \%$ Tween-20. All antibodies were diluted in PBS, 5\% gelatin hydrolysate, $0.1 \%$ Tween-20, and all incubations were carried out in $100 \mu 1$.

Ten $\mu 1$ of serial dilutions of synthetic defensin MGD1 (or MGD2) peptide solution $(1 \mathrm{mg} / \mathrm{ml})$ were brought to $100 \mu \mathrm{l}$ with $50 \mathrm{mM}$ $\mathrm{Na}_{2} \mathrm{CO}_{3}, \mathrm{pH}$ 9.6, and coated on flat-bottomed PVC 96-well microtiter plates (Becton Dickinson) by overnight incubation at $4^{\circ} \mathrm{C}$. After washing, PBS containing $20 \%$ gelatine hydrolysate was added for 1 hour at $20^{\circ} \mathrm{C}$. After washing, the wells were incubated for 1.5 hours at $37^{\circ} \mathrm{C}$ with $1: 2,000$ diluted mouse anti-defensin antiserum. After washing, the wells were incubated for 1 hour at $37^{\circ} \mathrm{C}$ with a goat alkaline-phosphatase labelled anti-mouse $\operatorname{IgG}$ antibody (BioSys) diluted 1:4,000. Finally, after washing, $100 \mu \mathrm{l}$ of $1 \mathrm{mg} / \mathrm{ml} p$ nitrophenyl phosphate in $0.2 \mathrm{M}$ Tris, $\mathrm{pH} 9.8$, were added for 30 minutes at $20^{\circ} \mathrm{C}$. The resulting coloration was measured at $405 \mathrm{~nm}$ using a Multiscan microplate colorimeter (Labsystem).

\section{RESULTS}

\section{Distribution of defensin MGD1, mytilin B and myticin $B$ expressing cells by in situ hybridisation}

Tissue sections of adult mussels were probed with DIG labelled antisense riboprobes and detected with alkaline phosphataseconjugated anti-DIG antibodies.

Defensin MGD1 mRNA were detected in some cells present in the digestive gland epithelia (Fig. 1A). According to their shape, these cells appeared to be infiltrating hemocytes. In addition, hybridisation was detected in circulating hemocytes found in sinuses (Fig. 1B).

Mytilin B mRNA were observed in some hemocytes present in sinuses of the digestive gland (Fig. 2A), gills (Fig. 2B) and 
adductor muscle (Fig. 2D). Numerous positive cells also infiltrated the epithelia in contact with the environment, such as digestive gland (Fig. 2A) and gills (Fig. 2B). Strong labelling was also detected in enterocytes (Fig. 2C), suggesting that these cells are also capable of expressing mytilin B. In order to investigate if enterocytes are also able to produce the peptide, mytilin immunohistochemistry was performed on digestive gland tissue sections. The results showed that mytilins are present in enterocytes (Fig. 2E).

Finally, myticin B mRNA were found (i) in some hemocytes
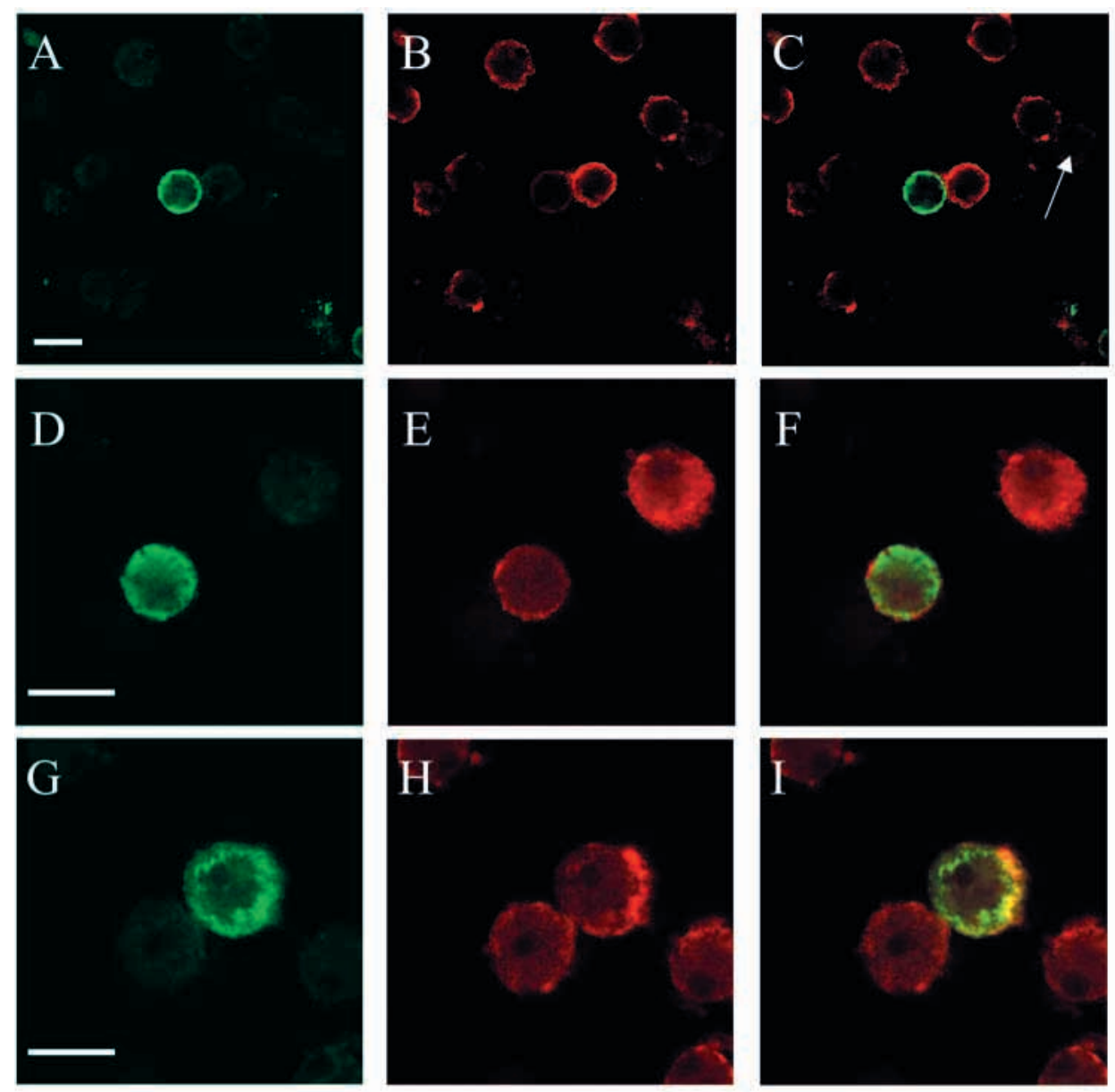

$\mathrm{J}$

$15 \%$

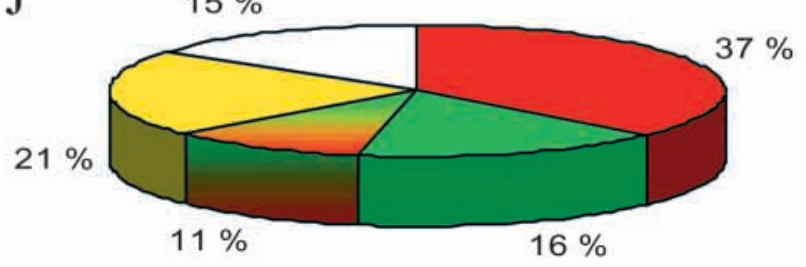

Fig. 4. Confocal microscopic images of defensins (green) and mytilins (red) double immune labelling in mussel circulating hemocytes. C, F, and I are the merged confocal images of A and B, $\mathrm{D}$ and $\mathrm{E}$, and $\mathrm{G}$ and $\mathrm{H}$, respectively. Merged confocal microscope images suggest that defensins and mytilins may be packed in different hemocytes (C), in the same hemocyte but in different compartments (F) or in the same compartments (I). Some hemocytes did not stain for defensin nor mytilin (C, arrow). Bar, $25 \mu \mathrm{m}$. (J) Relative percentages labelled circulating hemocytes as deducted from confocal observation of 700 hemocytes. Red: mytilins alone; Green: defensins alone; Red-green: mytilins and defensins in different cell compartments; Yellow: mytilins and defensins in the same cell compartments; Open: mytilins and defensins negative cells. in sinuses of the digestive gland (Fig. 3A), gills (Fig. 3B) and adductor muscle (Fig. 3D), and (ii) in cells present in gills (Fig. B) or intestine (Fig. 3C) epithelia. The shape of the positive hemocytes.

The specificity of these assays was confirmed in serial hybridised with the sense probes corresponding to (i) (Fig 2 $\mathrm{A}^{\prime}, \mathrm{B}^{\prime} \mathrm{C}^{\prime} \mathrm{D}^{\prime}$ ) and (iii) myticin $\mathrm{B}$ mRA (Fig. $\left.\mathrm{A}^{\prime}, \mathrm{B}^{\prime}, \mathrm{C}^{\prime}, \mathrm{D}^{\prime}\right)$. In addition, pre-treatment of sections with RNase A before hybridisation abolished the positive staining providing another evidence of the signal specificity (data not shown).

\section{Comparative distribution of defensins and mytilins in circulating hemocytes}

Antibodies used in this study were (i) a mouse antiserum directed against synthetic defensin MGD1 and (ii) rabbit polyclonal IgGs directed against native mytilin $B$. We demonstrated by ELISA that anti-defensin MGD1 antiserum recognised also the MGD2 isoform (data not shown). Consequently, we can not discriminate between the 2 defensin isoforms. Similarly, the high degree of homology between the different mytilin isoforms (Mitta et al., 2000) implies that the rabbit anti-mytilin B IgGs probably recognised the different isoforms. Consequently, we qualified any immune positive signals as related to the presence of defensins or mytilins.

To compare the distribution of defensins and mytilins, both peptides were detected in the same preparations using FITC and TexasRed, respectively, and examined by confocal microscopy. Defensinlabelling was detected as intensely fluorescent small spots distributed throughout the cytoplasm and surrounding the nucleus (Fig. 4A,D,G). Mytilin-immune reactivity was also detected throughout the cytoplasm, the labelling of which being more intense at the periphery of the cells (Fig. 4B,E,H). Different hemocytes can be positive for defensins only or for mytilins only (Fig. 4C), but both immune reactivities often appeared within the same cell (Fig. 4F-I). In the latter case, merged confocal microscope pictures suggested that defensins and mytilins can be packed in 

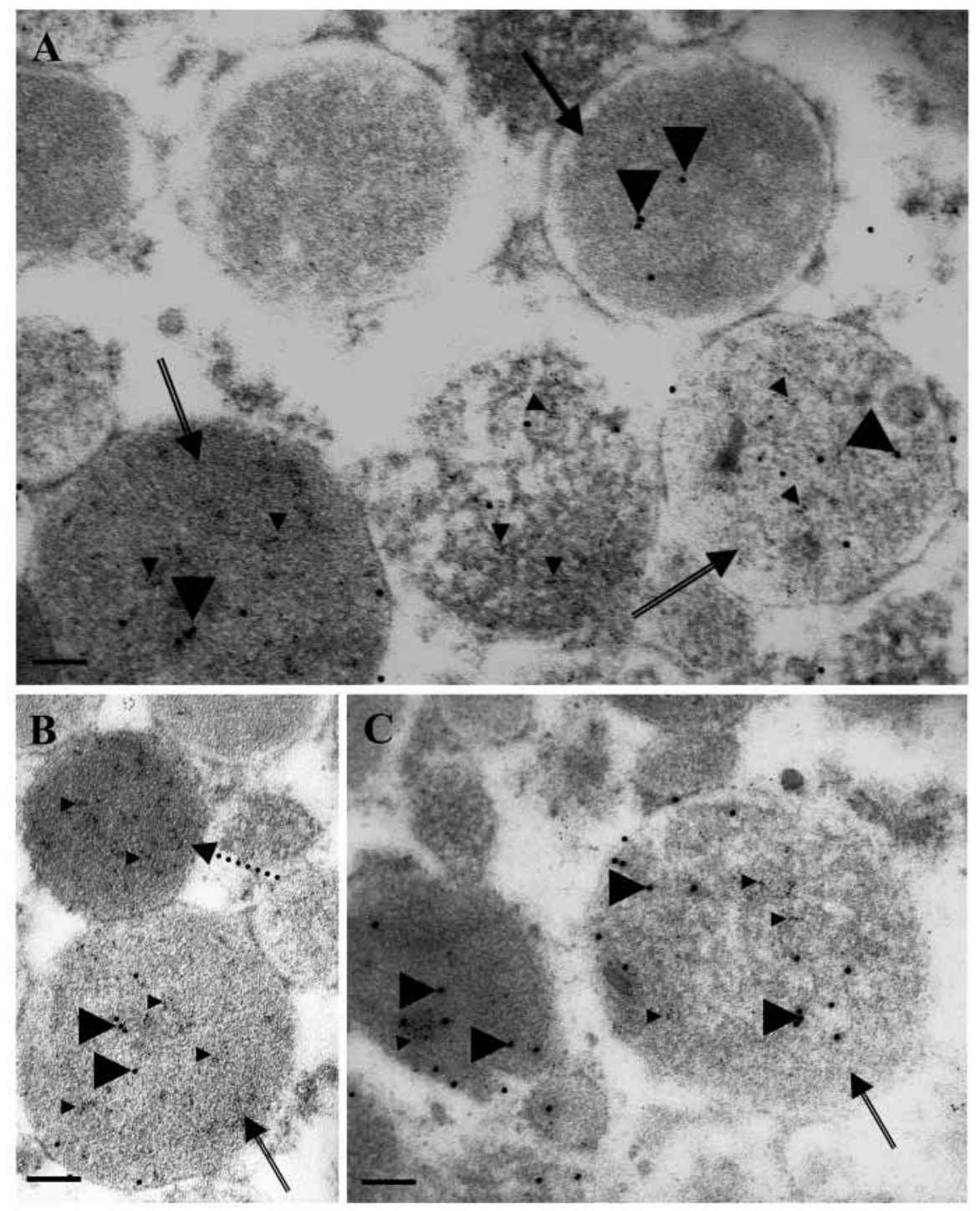

Fig. 5. Ultrastructural distribution (double immunogold labelling) of defensins and mytilins in circulating hemocytes. In A and B, the $18 \mathrm{~nm}$ gold particles (larger arrowheads) correspond to defensins and the $5 \mathrm{~nm}$ gold particles (smaller arrowheads) correspond to mytilins. Note the presence of granules containing (i) only defensins (arrow), (ii) only mytilins (dotted arrow) and (iii) both defensins and mytilins (double arrow). In $\mathrm{C}$, the $5 \mathrm{~nm}$ gold particles (smaller arrowheads) correspond to defensins and the $15 \mathrm{~nm}$ gold particles (larger arrowheads) correspond to mytilins. Bars: $0.5 \mu \mathrm{m}$ (A and C); $0.75 \mu \mathrm{m}(\mathrm{B})$.

different (Fig. 4F) or in the same (Fig. 4I) cell compartments. It is of importance that some hemocytes did not stain either for defensins nor for mytilins (Fig. 4C-J). Among 700 hemocytes observed by confocal microscopy, $37 \%$ of the cells stained positively only for mytilins, and $16 \%$ only for defensins, while $32 \%$ contained both labelling among which $21 \%$ exhibited a location in the same compartment. In addition, $15 \%$ of the cells were not labelled. When primary anti-defensin and anti-mytilin antibodies were omitted, respective FITC- and Texas-Red fluorescence was no longer observed in any of the slides examined (data not shown), providing evidence that no crossspecies reaction of secondary antisera had occurred.

In order to confirm the co-location of defensins and mytilins evidenced by confocal microscopy and to identify the cell compartment containing both peptides, double immunogold labelling using the anti-defensin and anti-mytilin antibodies was performed. Fig. 5 indicated that defensins and mytilins, revealed with 18 and $5 \mathrm{~nm}$-gold particles, respectively, are colocated in some granules of the granulocyte type containing large granules (Fig. 5A,B). Furthermore, to demonstrate the specificity of the labelling, the particle size revealing each peptide was inverted, i.e. $5 \mathrm{~nm}$ and $15 \mathrm{~nm}$-gold particles for defensins and mytilins, respectively. In this case, the same colocation in large granules was observed (Fig. 5C).

\section{Confrontation of hemocytes and bacteria}

In order to verify if mytilin-containing cells are capable of phagocytosis, hemocytes were incubated for 20 minutes in the presence of FITC-labelled $V$. alginolyticus and then treated for anti-mytilin immunocytochemistry (Texas-Red labelling). Observations with a confocal microscope showed that some hemocytes containing mytilins also contained phagocytosed 

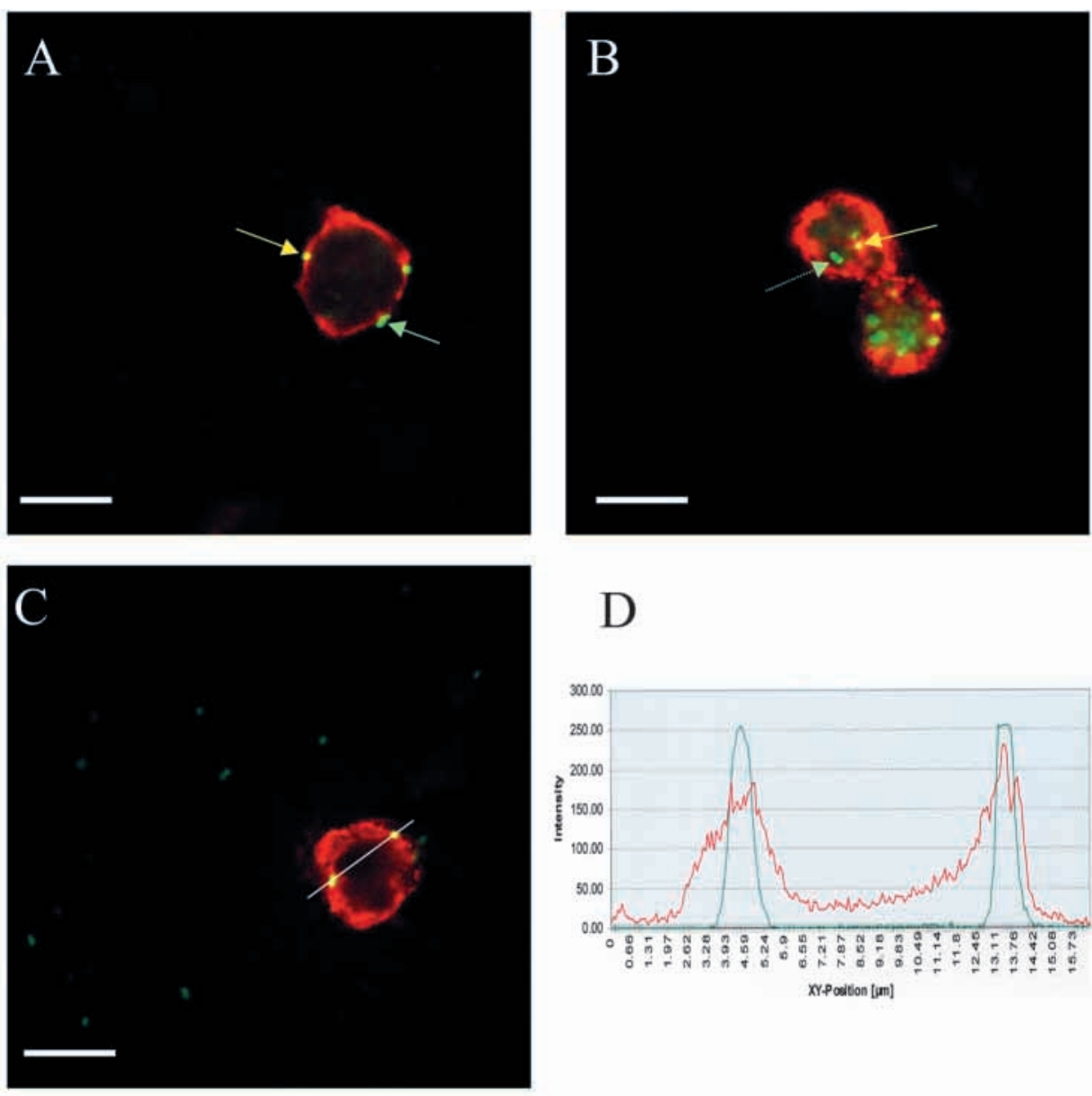

\section{D}
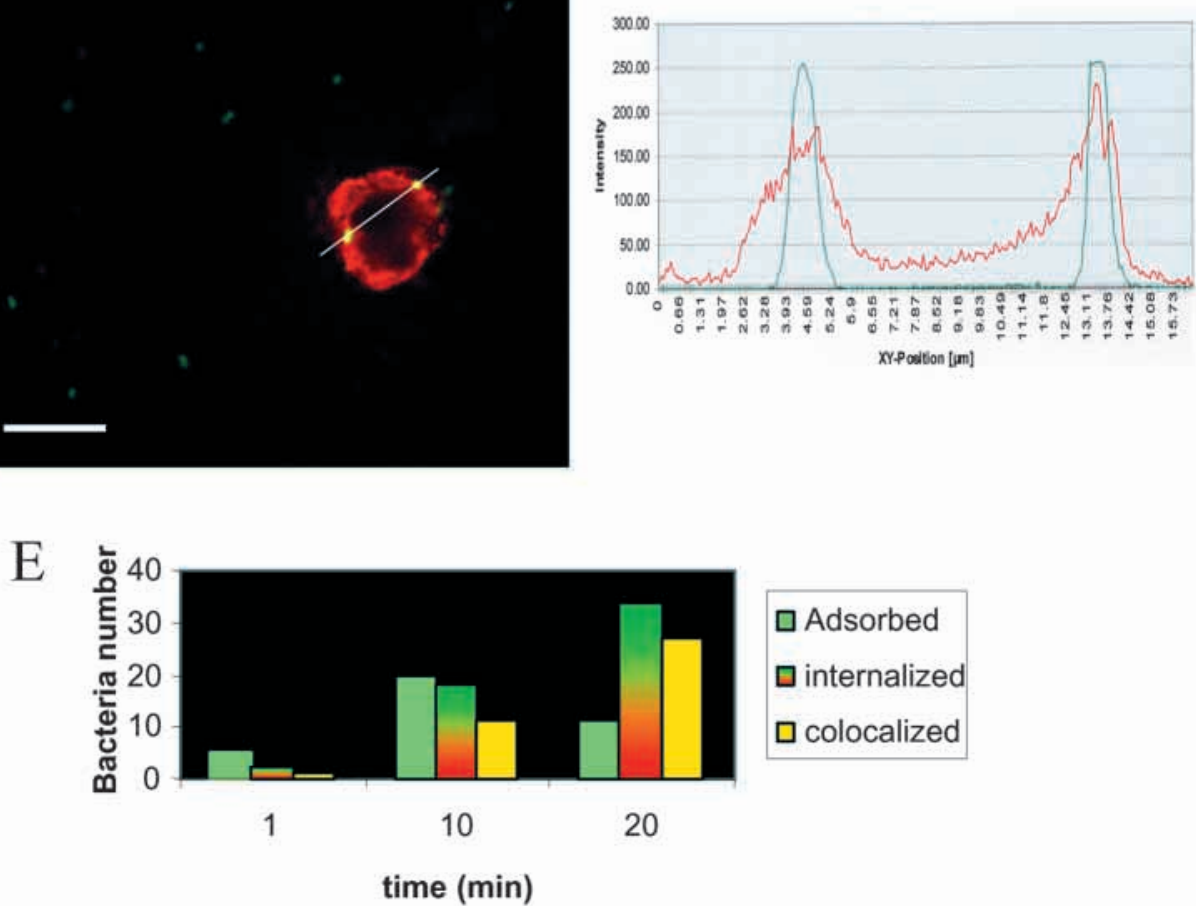

Fig. 6. Dual location of mytilins immune reactivity and phagocytosed fluorescent bacteria as observed by confocal microscopy. Hemocytes were incubated for 20 minutes in the presence of FITC-labelled Vibrio alginolyticus, then fixed and subjected to immune cytochemical detection of mytilins using a Texas-Red labelled secondary antibody. (B) Hemocyte containing mytilins was capable of phagocytosis (dotted green arrow). (A,B) Mytilin immune reactivity co-located with bacteria (yellow arrow). Measurement of fluorescence intensity along an axis crossing an hemocyte $(\mathrm{C})$ confirming that bacteria (green profile) are located in organelles containing mytilins (D, red profile). Bar: $10 \mu \mathrm{m}$ (E) Confocal microscopy was also used to quantify phagocytosis and co-location. E: Hemocytes were incubated in the presence of labelled bacteria and treated after various incubation times (1, 10 and 20 minutes) for immunocytochemistry. Histogram shows the number of adsorbed bacteria (A, green arrow), internalised bacteria (B, dotted green arrow) and bacteria co-located with mytilins (A and B, yellow arrow) counted in 100 random chosen hemocytes for each time of the kinetics.

bacteria (Fig. 6A,B). Furthermore, in some cases, mytilinreactivity and bacteria were found closely associated as demonstrated by the yellow coloration on merged images (Fig. 6B). Close association between bacteria (green fluorescence) and mytilins (red fluorescence) in the same cellular compartment was clearly demonstrated measuring the fluorescence intensity along an axis crossing an hemocyte (Fig. 6C,D).
In addition, confocal microscopy was used to quantify phagocytosis. Hemocytes were incubated in presence of labelled bacteria, then treated for mytilin-labelling after various incubation times (1, 10 and 20 minutes). Simply adsorbed bacteria, internalised bacteria, and bacteria closely associated with mytilins were counted in 100 randomly chosen hemocytes. Results demonstrated that the number of 
Fig. 7. Ultrastructural immune detection of mytilins in phagocytosing hemocytes. After being 20 minutes in contact with bacteria, hemocytes were fixed and mytilins revealed with a 15 nm gold particle-conjugated secondary antibody. (A) After phagocytosis, bacteria were found in phagosomes.

$(\mathrm{B}, \mathrm{C}, \mathrm{D})$ In numerous cases, mytilin immune reactivity colocalised with bacteria in cellular organelles. Exocytosis of some mytilin-containing granules into phagosomes suggested a probable fusion of the 2 organelles (C, arrow). n, nucleus, pl, phagolysosome; ps, phagosome. Bars: $1 \mu \mathrm{m}$ (A); $3 \mu \mathrm{m}$ (B and C); $0.5 \mu \mathrm{m}$ (D).

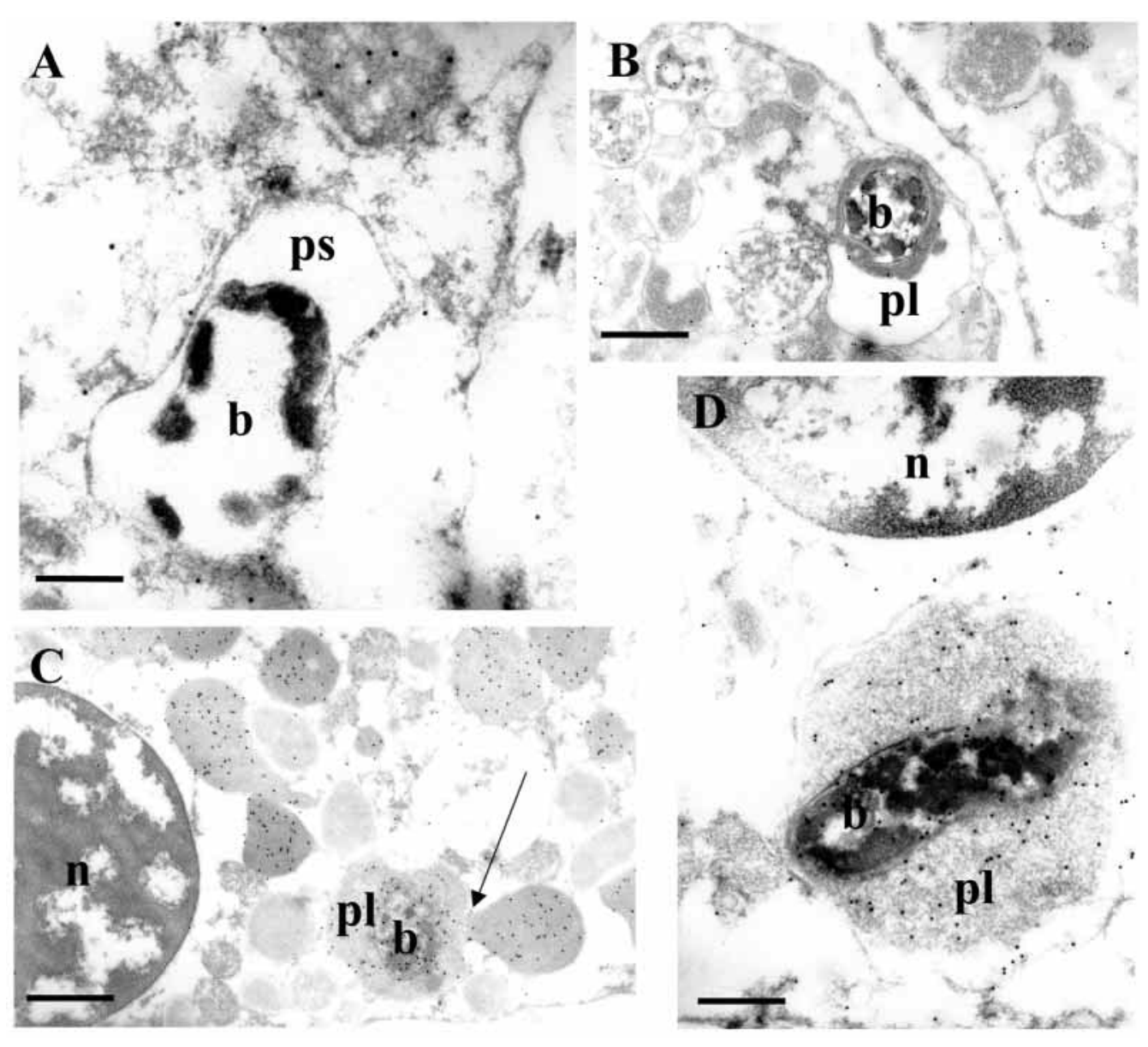

internalised bacteria increased with time, as well as the number of mytilin-bacteria co-location events (Fig. 6E). In contrast, the number of adsorbed bacteria, which increased on the first 10 minutes, decreased on 20 minutes, at the time where numerous bacteria were internalised. This suggested that bacteria were first adsorbed on the hemocyte surface, then internalised into phagosomes. Later, phagosomes and mytilin containing granules will fuse leading to the observed co-location of the peptides and ingested bacteria.

Sub-cellular location of bacteria and mytilins was investigated on hemocytes incubated with bacteria for 20 minutes and then treated for mytilin immunogold labelling. As previously observed, bacteria were found in hemocytes containing mytilin-reactivity (Fig. 7). In some cases, phagocytosed bacteria were found sequestered in phagosomes (Fig. 7A). In numerous cases, mytilin-labelling was observed inside cellular organelles that also contained bacteria (Fig. 7B,C,D). Open contacts between mytilin-containing granules and phagosomes argued in favour of their fusion (Fig. 7C). No bacteria were observed in mytilin negative cells. Furthermore, using the same methodology, no defensin-labelling was evidenced in phagocytes.

\section{DISCUSSION}

In previous studies, three antimicrobial peptide types were purified from hemocytes (Mitta et al., 1999a,b, 2000). Such a diversity, extended by the presence of isoforms, is questionable. The first biological significance of this diversity was given by the studies on activity spectrum established for the different isolated molecules (Hubert et al., 1996; Mitta et al., 1999a, 2000). In fact, the different peptide families and isoforms possess complementary properties. This might permit an increase in antimicrobial capabilities of mussels confronted in their environment with a high diversity of pathogens. In the present study, another biological significance of the peptide diversity was hypothesised by comparing the distribution of the cells expressing the peptides. Indeed, we discovered a differential distribution of these cells throughout the mussel body. Whereas numerous defensin expressing cells were shown to infiltrate the digestive tubule epithelia, mytilin and myticin expressing cells are respectively much less or not represented in these epithelia. In addition, mytilin and myticin expressing cells are well represented in gills, whereas no defensin positive cells were found in this tissue. Consequently, the peptide diversity could be partially explained by their spatial involvement in different areas of the organism. Results concerning the partitioning of defensin- and mytilin-containing hemocytes in the population of circulating hemocytes also support this hypothesis. In fact, defensins and mytilins seem to be partially distributed in different hemocyte sub-types. 37\% of the circulating hemocytes contained only mytilins and $16 \%$ of the cells contained only defensins. Consequently, the 2 peptides could be transported to different organs to ensure their antimicrobial role. 
As defensin immune reactivity was never detected in phagocytosing cells, the granulocyte sub-type containing exclusively mytilins seems to be the only one involved in bacteria phagocytosis. Furthermore, we demonstrated by confocal microscopy that a sub-population of circulating hemocytes contained both defensins and mytilins. The role of this latter hemocyte sub-type remains to be elucidated. In previous studies, we showed that bacterial challenge triggered a plasmatic increase of defensin and mytilin concentrations 24 hours after and gave evidence on the hemocyte origin of the released peptides, i.e. exocytosis figures of mytilin-containing granules and shifting of defensin-immune reactivity towards the plasma membrane (Mitta et al., 1999b, 2000). Granulocytes containing both peptides could be involved in these simultaneous plasmatic increases. Co-location in the same granules evidenced by both confocal and electron microscopies supports the hypothesis that both peptides are simultaneously released by exocytosis. Consequently, the granulocytes containing only mytilins and the one containing both defensins and mytilins, are probably involved at different stages of the anti-infectious response. The first sub-type would be involved in an early phase response by migrating towards infectious site and phagocytosing micro-organisms, the second sub-type being involved at a later stage by releasing the peptides for a systemic response.

In the present work, we demonstrated the presence of mytilin $B$ messengers and peptides in enterocytes. In a previous study, immunocytochemistry on tissues have revealed the presence of defensin-like substances in the intestine epithelium and we demonstrated that these molecules were located in granular structures contained in enterocytes (Mitta et al., 1999b). Such a location of antimicrobial peptide expression in epithelial cells of gastrointestinal tracts has been reported in insects (Lehane et al., 1997; Ferrandon et al., 1998) and mammals, where they were found in Paneth cells (Ouellette and Selsted, 1996). In these species, antimicrobial peptides participated in a local defence against micro-organisms. Our data suggest that a similar mechanism of mucosal defence in the intestine also exists in mussels.

We recently reported that large granules of mussel hemocytes contain antimicrobial peptides, such as mytilins (Mitta et al., 2000). Other studies have shown the presence of a range of hydrolytic enzymes, including proteinases, glycosidases and sulphatases, within the large granules of mussel hemocytes (Pipe, 1990b). All these data suggest that the large granules are lysosome-like. In addition, we demonstrate in this paper that (i) the cell type containing mytilin immune reactivity was able to phagocytose bacteria, (ii) internalised bacteria are first located in phagosome-like structures, and (iii) bacteria co-located with mytilins in the same organelles. Furthermore, exocytosis of some mytilin-containing granules into phagosomes were evidenced suggesting a fusion of phagosomes with mytilincontaining granules.

In the insect, Drosophila melanogaster, a variety of peptides are rapidly synthesised in fat body cells after bacterial challenge and immediately secreted into the hemolymph leading to a systemic response. Hemocytes of the chelicerate, Tachypleus tridentatus, produce antimicrobial peptides that are stored in hemocytes (Shigenaga et al., 1990). Upon stimulation by microbial substances, hemocytes degranulated and released into the plasma a series of substances involved in immune defence, including the antimicrobial peptides (see Iwanaga et al., 1998 for review). In contrast, the mytilin model exhibits similarities with that described for human neutrophil $\alpha$ defensin peptides, in which neutrophil defensins are stored in azurophil granules that discharge their contents into microbecontaining phagosomes through a process of phagosomegranule fusion (Ganz et al., 1985). Within the phagolysosome, micro-organisms may encounter high antimicrobial peptide concentrations suitable to kill them.

Our data strengthen the similarities of mussel hemocytes with cells of the human monocyte/macrophage lineage. Indeed, mussel hemocytes are capable of (i) non-self recognition mediated by lectins (Renwrantz et al., 1985; Pipe, 1990a), (ii) chemotactic migration towards invading pathogens (Cheng and Howland, 1979; Stefano et al., 1989), (iii) attachment and endocytosis of the pathogen (for review see Renwrantz, 1990), (iv) killing of pathogens by reactive oxygen intermediates and enzymes (Carballal et al., 1997), and also antimicrobial peptides.

Recent data have highlighted similarities between pathogen recognition and signalling pathways of innate immunity in arthropods and mammals (Hoffmann et al., 1999). We describe here a new invertebrate model of antimicrobial peptide involvement in anti-infectious processes that is closely related to that of mammals. All together, these data suggest that vertebrate innate immunity is a patchwork of ancestral mechanisms still existing in primitive animals.

We are grateful to Dr Bernard Calas and Dr Alain Chavanieu (Université Montpellier 1) for defensin MGD1 synthesis. We thank Annie Desmons for technical assistance. DRIM is a join research unit (UMR 5098) funded by IFREMER, CNRS and Université de Montpellier 2. The Laboratoire d'Endocrinologie des Annélides was the recipient of a special 'Incitation IFREMER grant' for 1999. This work has been partially carried out with the financial support from the Commission of the European Communities, Agriculture and Fisheries (FAIR) specific RTD programme, CT 97-3691. It does not necessarily reflect its views and in no way anticipates the Commission's future policy in this area.

\section{REFERENCES}

Anguiano-Beltran, C. (1996). Patogenicidad de Vibrio alginolyticus sobre larvas del mejillon europeo Mytilus galloprovincialis y larvas y postlarvas del abulon rojo Haliotis rufescens. MS thesis, CICESE, Ensenada, BC, Mexico.

Bachère, E., Hervio, D. and Mialhe, E. (1991). Luminol-dependent chemiluminescence by hemocytes of two marine bivalves, Ostrea edulis and Crassostrea gigas. Dis. Aquat. Org. 11, 173-180.

Broekaert, W. F., Terras, F. R., Cammue, B. P. and Osborn, R. W. (1995). Plant defensins: novel antimicrobial peptides as components of the host defense system. Plant. Physiol. 108, 1353-1358.

Bulet, P., Hétru, C., Dimarcq, J. L. and Hoffmann, D. (1999). Antimicrobial peptides in insects; structure and function. Dev. Comp. Immunol. 23, 329344 .

Carballal, M. J., Lopez, C., Azevedo, C. and Villalba, A. (1997). Enzymes involved in defense functions of hemocytes of mussel Mytilus galloprovincialis. J. Invertebr. Pathol. 70, 96-105.

Charlet, M., Chernysh, S., Philippe, H., Hétru, C., Hoffmann, J. and Bulet, P. (1996). Innate immunity. Isolation of several cysteine-rich antimicrobial peptides from the blood of a mollusc, Mytilus edulis. J. Biol. Chem. 271, 21808-21813.

Cheng, T. C. and Howland, K. H. (1979). Chemotactic attraction between hemocytes of the oyster, Crassostrea virginica, and bacteria. J. Invertebr. Pathol. 33, 204-210. 
Faure-Virelizier, C., Croix, D., Bouret, S., Prevot, V., Reig, S., Beauvillain, J. C. and Mitchell, V. (1998). Effects of estrous cyclicity on the expression of the galanin receptor Gal-R1 in the rat preoptic area: a comparison with the male. Endocrinology 139, 4127-4139.

Ferrandon, D., Jung, A. C., Criqui, M., Lemaitre, B., Uttenweiler-Joseph, S., Michaut, L., Reichart, J. and Hoffmann, J. A. (1998). A drosomycinGFP reporter transgene reveals a local immune response in Drosophila that is not dependent on the Toll pathway. EMBO J. 17, 1217-1227.

Ganz, T., Selsted, M. E., Szklarek, D., Harwig, S. S., Daher, K., Bainton, D. F. and Lehrer, R. I. (1985). Defensins. Natural peptide antibiotics of human neutrophils. J. Clin. Invest. 76, 1427-1435.

Ganz, T. and Lehrer, R. I. (1997). Antimicrobial peptides of leukocytes. Curr. Opin. Hematol. 4, 53-58.

Hoffmann, J. A., Kafatos, F. C., Janeway, C. A. and Ezekowitz, R. A. (1999). Phylogenetic perspectives in innate immunity. Science 284, 13131318.

Hoffmann, J. A., Reichart, J. M. and Hetru, C. (1996). Innate immunity in higher insects. Curr. Opin. Immunol. 8, 8-13.

Hubert, F., Noël, T. and Roch, Ph. (1996). A member of the arthropod defensin family from edible Mediterranean mussels, Mytilus galloprovincialis. Eur. J. Biochem. 240, 302-306.

Iwanaga, S., Kawabata, S. I. and Muta, T. (1998). New types of clotting factors and defense molecules found in horseshoe crab hemolymph: their structure and functions. J. Biochem. 123, 1-15.

Lehane, M. J., Wu, D. and Lehane, S. M. (1997). Midgut-specific immune molecules are produced by the blood-sucking insect Stomoxys calcitrans. Proc. Nat. Acad. Sci. USA 94, 11502-11507.

Lehrer, R. I. and Ganz, T. (1999). Antimicrobial peptides in mammalian and insect host defence. Curr. Opin. Immunol. 11, 23-27.

Mitta, G., Hubert, F., Noël, T. and Roch, Ph. (1999a). Myticin, a novel cysteine-rich antimicrobial peptide isolated from hemocytes and plasma of the mussel Mytilus galloprovincialis. Eur. J. Biochem. 265, 71-78.

Mitta, G., Vandenbulcke, F., Hubert, F. and Roch, Ph. (1999b). Mussel defensins are synthesised and processed in granulocytes then released into the plasma after bacterial challenge. J. Cell Sci. 112, 4233-4242.

Mitta, G., Vandenbulcke, F., Hubert, F., Salzet, M. and Roch, Ph. (2000). Involvement of mytilins in mussel antimicrobial defence. J. Biol. Chem. 275, 12954-12962.

Ouellette, A. J. and Selsted, M. E. (1996). Paneth cell defensins: Endogenous peptide components of intestinal host defense. FASEB J. 10, 1280-1289.

Pipe, R. K. (1990a). Differential binding of lectins to hemocytes of the mussel, Mytilus edulis. Cell Tissue Res. 261, 261-268.

Pipe, R. K. (1990b). Hydrolytic enzymes associated with the granular hemocytes of the marine mussel, Mytilus edulis. Histochem. J. 22, 595603.

Renwrantz, L., Daniels, J. and Hansen P. D. (1985). Lectin-binding to hemocytes of Mytilus edulis. Dev. Comp. Immunol. 9, 203-210.

Renwrantz, L. (1990). Internal defense system of Mytilus edulis. In Neurobiology of Mytilus edulis, G. Stephano (Ed). Manchester University Press, 256-275.

Schroder, J. M. (1999). Epithelial peptide antibiotics. Biochem. Pharmacol. 57, 121-34

Shigenaga, T., Muta, T., Toh, Y., Tokunaga, F. and Iwanaga, S. (1990). Antimicrobial tachyplesin peptide precursor cDNA cloning and cellular localisation in the horseshoe crab, Tachypleus tridentatus. J. Biol. Chem. 265, 21350-21354.

Stefano, G. B., Leung, M. K., Zhao, X. and Scharrer, B. (1989). Evidence for the involvement of opioid neuropeptides in the adherence and migration of immunocompetent invertebrate hemocytes. Proc. Nat. Acad. Sci. USA 86, 626-630. 